\title{
Two New Species of Primula (Primulaceae) from China
}

\author{
Hu Chi Ming \\ South China Institute of Botany, Academia Sinica, Guangzhou 510650, \\ People's Republic of China. huqm@scib.ac.cn \\ Geng Yu Ying \\ West China Subalpine Botanical Garden, Institute of Botany, Academia Sinica, \\ Dujiangyan 611830, China
}

Abstract. Two new species of Primula from western China are described, illustrated, and compared with putatively related species. Both new species belong to section Petiolares subsect. Davidii (Balfour f.) Craib, which is characterized by the capsule crumbling irregularly at maturity, the basal buds always having a covering of paleaceous scales, and the leaves being more or less coriaceous, persisting into the following spring, with veins often prominently raised and alveolate abaxially and impressed adaxially. In this subsection there are about 18 species all distributed in Sichuan or Yunnan, with only one species extending to Guizhou, Hubei, Hunan, and Jiangxi.

Key words: China, Primula, Primulaceae.

Since the publication of the Primulaceae treatment in the Flora Reipublicae Popularis Sinicae (Hu, 1990), the authors carried out a project of introducing wild species of Primula for cultivation in the West China Subalpine Botanical Garden in Dujiangyan City in Sichuan Province. In the process we rediscovered $P$. davidii Franchet and $P$. filchnerae Knuth, both of which were previously known only from the type material collected nearly a century ago. In addition, we discovered two new species belonging to section Petiolares subsect. Davidii, characterized by the capsule crumbling irregularly at maturity, the basal buds always having a covering of paleaceous scales, and the leaves being more or less coriaceous, persisting into the following spring, with veins often prominently raised and alveolate abaxially and impressed adaxially. In this subsection there are about 18 species all distributed in Sichuan or Yunnan, with only one species extending to Guizhou, Hubei, Hunan, and Jiangxi. The new species are described here.

Primula bergenioides C. M. Hu \& Y. Y. Geng, sp. nov. TYPE: China. Sichuan: Emei Shan, Jing Shui, alt. 1105 m, 17 Mar. 1994, Y. Y. Geng 94-003 (holotype, IBSC). Figure 1.
Species affinis $P$. hylobiae et $P$. klaverianae, a quibus foliis scapisque glabrissimis, calyce tantum ad tertiam partem in lobos ovatos fisso differt; ab altera etiam floribus heterogeneis differt.

Perennial herbs, efarinose, with a short comparatively stout rhizome, basally with brown paleaceous bud-scales at flowering time. Leaves forming a spreading rosette, to $30 \mathrm{~cm}$ diam.; leaf blade oblong-elliptic to elliptic-obovate, $12-20 \times 6-9 \mathrm{~cm}$, apex rounded, tapering from the middle into a very short or almost obsolete winged petiole, irregularly crenate-dentate, papery when dry, \pm bullate on the margin and covered with minute glandular hairs when just unfolded from the resting buds, soon glabrate, smooth and quite glabrous on both surfaces when mature; lateral veins 11 to 13 pairs, plane adaxially, raised abaxially, subparallel, angled to midrib ca. $65^{\circ}$, secondary veins obscure on both surfaces. Scapes $13-20 \mathrm{~cm}, 1$ to 2 per plant, glabrous, carrying a terminal umbel of 5 to 11 flowers; bracts lanceolate, 5-8 mm long, brown, paleaceous, glabrous; pedicels $1-1.5 \mathrm{~cm}$, elongated to $2.5 \mathrm{~cm}$ in fruit, sparsely glandular-puberulent. Flowers heteromorphic; calyx narrowly campanulate, 10-12 mm long, glandular-puberulent, 5-veined, split to a third of its length; lobes ovate, ca. $3.5 \mathrm{~mm}$ wide, apex acute; corolla funnel-shaped, lavender-blue, exannulate. Thrum flower: corolla tube ca. $13 \mathrm{~mm}$ long, cylindrical, ampliate above insertion of stamens; limb 1.8-2.5 cm across; lobes obovate, $9 \times$ $8 \mathrm{~mm}$, apex emarginate; stamens inserted at apex of corolla tube; filaments ca. $1.5 \mathrm{~mm}$; anthers linear, ca. 2 mm long; style 5-6 mm long; stigma capitate. Capsule subglobose, included in calyx tube.

Distribution and habitat. Known only from the type locality, growing in fissures on dripping wet sandstone cliffs.

Primula bergenioides is most closely related to P. hylobia W. W. Smith and P. klaveriana Forrest. From both it can be easily distinguished by its glabrous leaves and scapes and by its calyx splitting

Novon 13: 196-199. 2003. 


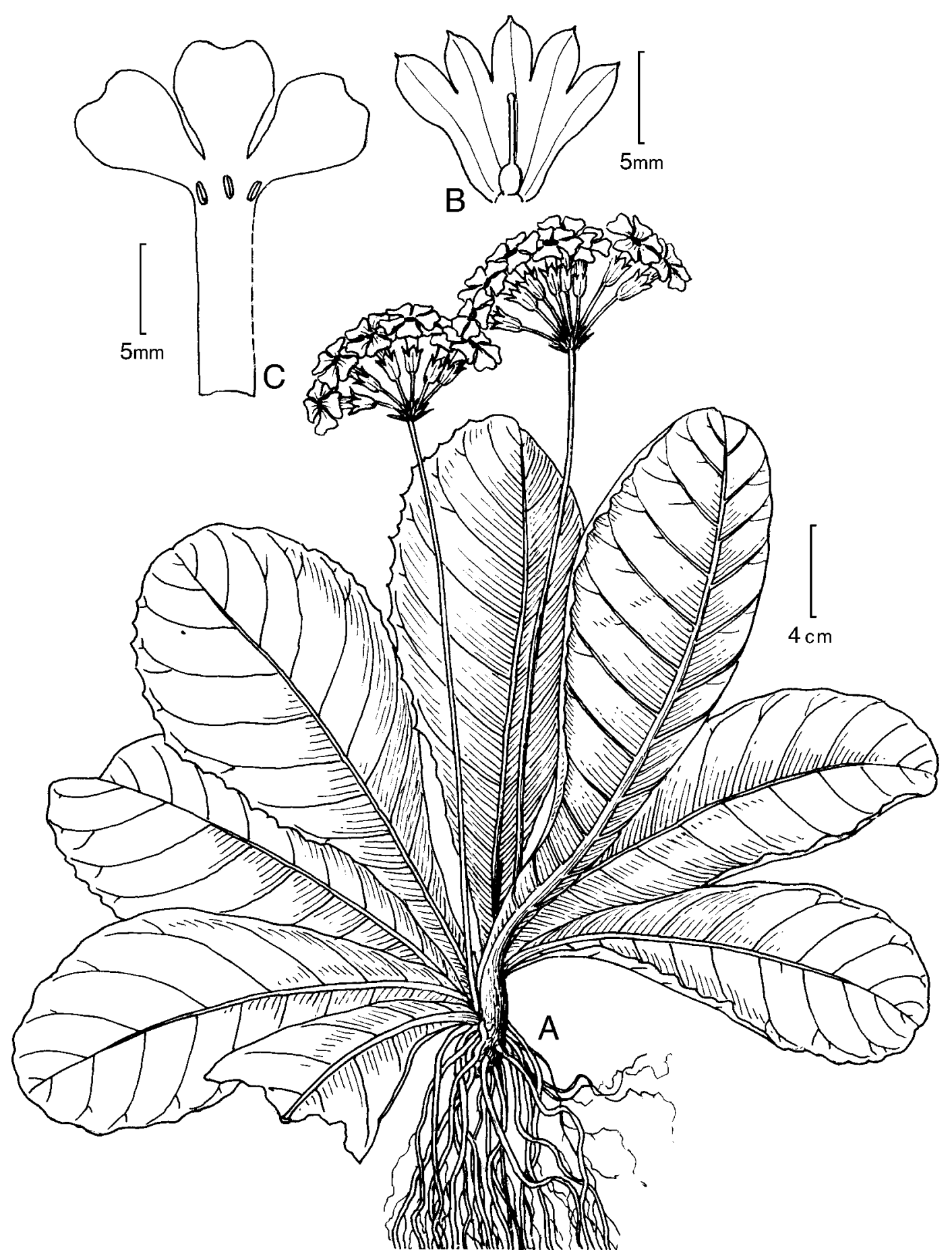

Figure 1. Primula bergenioides C. M. Hu \& Y. Y. Geng. - A. Habit. —B. Calyx opened up to show pistil. —C. Short-styled flower: portion of opened corolla showing stamens. (Drawn from the holotype.) 


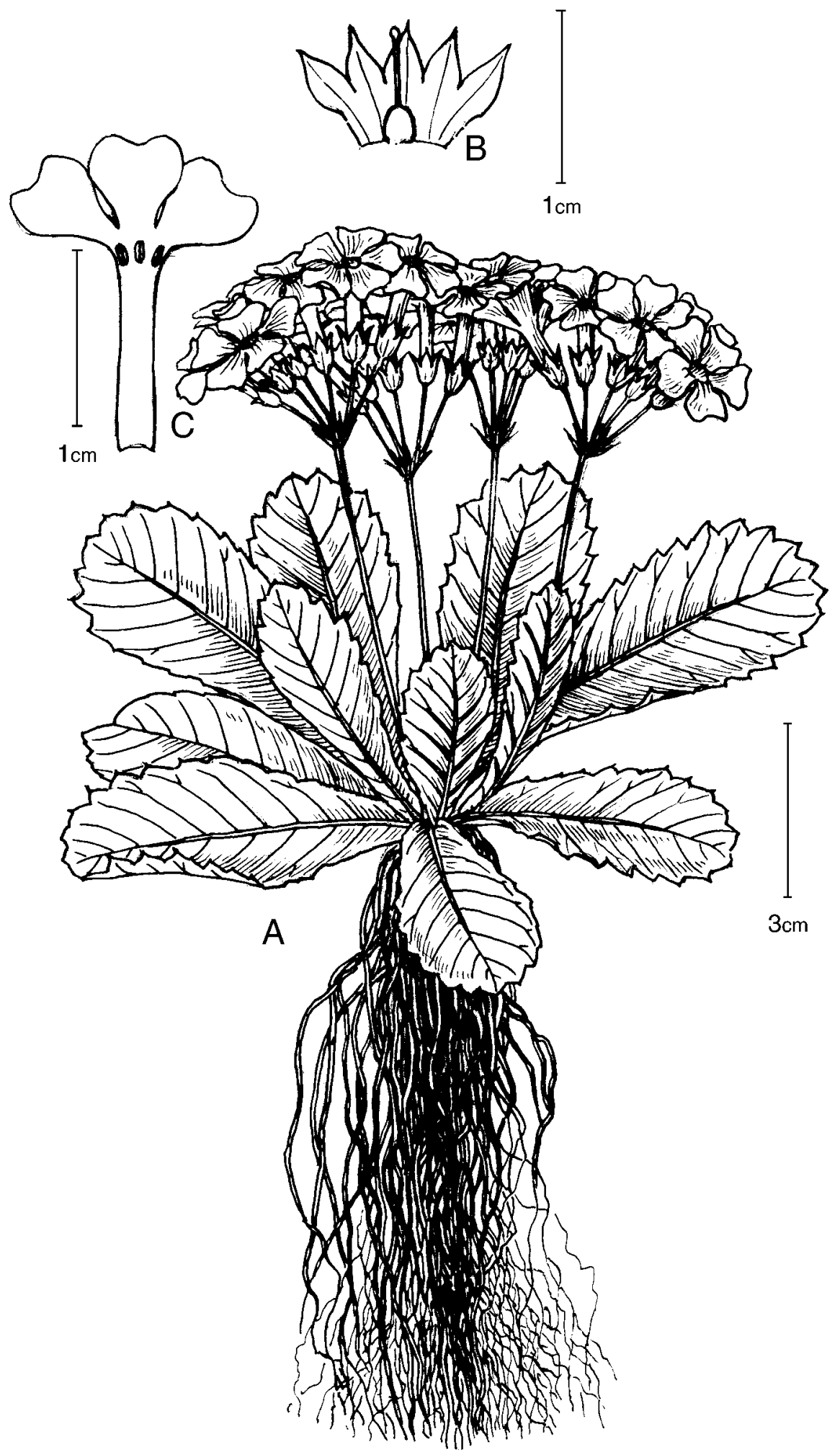

Figure 2. Primula tenuituba C. M. Hu \& Y. Y. Geng. -A. Habit. -B. Calyx opened up to show pistil. —C. Shortstyled flower: portion of opened corolla showing stamens. (Drawn from the holotype.) 
only to a third of its length (not to the middle as in the above-mentioned species). Moreover, it stands apart from $P$. klaveriana by its heterogeneous flower.

The specific epithet refers to the comparatively large and dark green leaves, which look somewhat like those of Bergenia.

Paratype. CHINA. Sichuan: Emei Shan, Jing Shui, 7 May 1990, C. M. Hu 9067 (IBSC).

Primula tenuituba C. M. Hu \& Y. Y. Geng, sp. nov. TYPE: China. Sichuan: Ying Jing Xian, Hua Tan Xiang, Li Jia Yan, alt. 800 m, 14 May 1992, Y. Y. Geng, Z. L. Zhao et al. 92001 (holotype, IBSC). Figure 2.

Species valde affinis $P$. epilosae Craib, sed floribus minoribus, tubis corollarum tenuioribus, foliis scapis inflorescentiisque glabris, rete venularum invisibili differt.

Perennial herbs with a comparatively stout rhizome from which arise numerous fibrous roots and clothed at base by withered old leaves. Leaves forming a rosette to $15 \mathrm{~cm}$ diam.; leaf blade $5-8 \times$ $1.5-3 \mathrm{~cm}$ at flowering time, $7-11 \times 2.5-3.5 \mathrm{~cm}$ at fruiting, oblong-obovate to oblanceolate, tapering from a rounded apex into a very short or almost obsolete winged petiole, irregularly crenate-dentate at margin, thickly papery, adaxial surface scurfyglandular at flowering, glabrous when mature, \pm white farinose on abaxial surface; lateral veins 8 to 11 pairs, prominent on abaxial surface, angled to the midrib ca. $60^{\circ}$, ending in teeth, secondary veins very obscure or invisible. Scapes $4.5-6 \mathrm{~cm}$ long, 1 to 4 per plant, glabrous, carrying a terminal umbel of 3 to 7 flowers; bracts $3-4 \mathrm{~mm}$ long, acuminate from the broad base, brown, paleaceous; pedicels $1.2-1.5 \mathrm{~mm}$, lengthening to $2 \mathrm{~cm}$ in fruit, glabrous. Flowers heteromorphic; calyx campanulate, ca. 7 mm long, 5-veined, glabrous, split almost to middle; lobes ovate, acuminate; corolla violet-blue. Thrum flower: corolla tube slender, ca. $12 \mathrm{~mm}$ long, ampliate above insertion of stamens, limb ca. 1.8 cm diam.; lobes obovate, ca. $7 \mathrm{~mm}$ long, deeply emarginate; stamens inserted near apex of corolla tube; filaments very short; anthers ca. $1.5 \mathrm{~mm}$ long; ovary glabrous; style ca. $5 \mathrm{~mm}$ long. Capsule globose, slightly shorter than the persistent calyx.

Distribution and habitat. Known only from the type locality in Sichuan, growing on exposed cliffs near a waterfall; alt. ca. $800 \mathrm{~m}$.

Primula tenuituba is most closely related to $P$. epilosa Craib, from which it differs by the smaller flowers with a very slender corolla tube and by the leaves being glabrous and not strongly reticulate with a network of veinlets on the abaxial surface.

The specific epithet refers to the slender corolla tube of the plant.

Paratype. CHINA. Sichuan: Ying Jing Xian, Hua Tan Xiang, Li Jia Yan, alt. 800 m, 17 May 1990, Y. Y. Geng, Z. L. Zhao et al. 90068 (IBSC).

Acknowledgments. This study was supported by a grant from the National Science Foundation of China (39970053). We thank Ihsan A. Al-Shehbaz for his review of the manuscript prior to submission.

\section{Literature Cited}

Hu, C. M. 1990. Primulaceae (2). In: F. H. Chen \& C. M. Hu (editors), Flora Reipubl. Popularis Sin. 59(2): 1317. Science Press, Beijing. 